\title{
The Importance of Globalisation and Learning Capital for Economic Growth
}

\author{
Mária Antalová ${ }^{1, *}$ \\ ${ }^{1}$ Department of Social Development and Labor, Faculty of National Economy, University of \\ Economics in Bratislava, Slovakia
}

\begin{abstract}
.
Research background: In our paper, we focus on two important phenomena that are currently culminating and bringing their positive as well as negative consequences. They are globalization and the learning capital. In research, experts are primarily oriented on globalization, which we perceive so intensely in our daily lives. There exist extensive studies developed on a theoretical, methodological as well as empirical basis. Experts are intensively dealing also with the human capital and, above all, with its impact on various socio-economic phenomena. However, they are paying less attention to the learning capital, which we consider one dimension of the human capital.

Purpose of the article: Link between the human capital and the economic growth has long been clarified, but the relation between the learning capital is not remained at forefront of the research intentions. For this reason, we have decided to examine the interconnectedness between globalization and the learning capital in selected EU countries and to determine its contribution to the economic growth.

Methods: In quantification of globalization, we use the overall KOF Globalization Index, which consists of 3 components: the economic, social and political dimensions. There does not exist uniform procedure for examining the learning capital. For this reason, we rely on Human Development Index data.

Findings \& Value added: In the empirical analysis, we focus on the evaluation of the current state of globalization as well as the learning capital in the Slovak Republic and verify the established hypotheses concerning the interconnection of these two phenomena and their impact on the economic growth.
\end{abstract}

Keywords: globalization; human capital; learning capital; economic growth

JEL Classification: $A 14 ; A 20 ; I 25 ; J 24$

* Corresponding author: maria.antalova@euba.sk 


\section{Introduction}

In our paper, we focus on three important phenomena that are currently culminating and bringing their positive as well as negative consequences. They are globalization, the learning capital and the economic growth. There are extensive studies on globalization, developed on a theoretical, methodological as well as empirical basis. With the same level of research, we can meet the concept of the economic growth. Experts explore less the learning capital. They prefer category of the human capital, which they can measure through the human development index or other indicators. So far, we have not encountered a study linking the development and current state of globalization, the learning capital and the economic growth. For this reason, we aim to examine the interconnectedness between globalization and the learning capital in selected EU countries and to identify their impact on the economic growth.

\section{Theoretical Framework}

\subsection{Definition of Globalization, Learning Capital and Economic Growth}

Globalization is a new phenomenon of the $20^{\text {th }}$ century [1], which researchers are dealing with from different scientific disciplines, not only in terms of economics $[2,3]$ and finance $[4,5]$, but also politics [6], culture, environment, psychology, social psychology, and so on. In spite of all their efforts, its identification remains inconsistent and, for its global character, on a high level of abstraction, which causes the different approaches to its operationalization and quantification [7]. Experts of the OECD regard globalization as "... the process by which markets and production are becoming more dependent in different countries for the dynamics of commodity, services and mobility of capital and technology" $[8,16,17]$. According to this definition we can deduce, that globalization is a process that erodes national boundaries, integrates national economies, cultures, technologies and governance, and produces complex relations of mutual interdependence, which is leading to integration not only in economic but also in social area $[9,10]$. From our approach we shall understand under globalization its overall manifestation in its economic, social and political implications, and focus on its connection to the learning capital and economic growth.

Another the central category of our paper is the learning capital, which we find to represent one dimension of the human capital. As a reasoning for our statement, we present the ideas of G. S. Becker, who in his work "Human Capital" perceived man as a being with universal abilities, skills and abilities, applicable more or less in every field of human activity, but also with specific knowledge and skills applicable only in a particular field or type of activity [11]. Over the course of 30 years, his theory has been further developed through the efforts of other authors [12-14]. Some came up with the idea of uncovering parts in it. Thus, the social capital began to be perceived as one dimension of the human capital [15], later the knowledge capital and other types were added to it.

The development and completion of category of the human capital, according to our opinion, was related to the social changes, which brought new types of societies [16], such as the learning society, the knowledge society, the creative society and according to us also the social quality Each of them presupposes the specific skills of the workforce - different from the current needs. The completion of the theory in their intentions gradually put pressure on its content, which ceased to meet new needs. Efforts have been made to increase the perception of the human capital [17]. And so at present we can talk about the following dimensions of people's competencies: the learning dimension, the knowledge dimension, the creative dimension and the social dimension. R. Edwards defines a learning 
society as a society that manifests itself in increased citizen activity, democracy and equal opportunities [18]. He underlined in his work the fact that modern life and economic, technological, social, demographic and cultural changes have created the specific problems, the solution of which requires the application of new forms of learning as well as new knowledge and skills. At present time we can summarize following characteristics of the learning society:

1. It is an educated society characterized by active citizens, liberal democracy and equal opportunities. It aims to provide the learning opportunities to educate adults to respond to the challenges of the societal change.

2. It is characterized by a learning market, representing the educational institutions providing educational services to individuals in order to promote the competitiveness of economy.

3. It creates learning networks that arise when individuals accept a learning approach to their lives. They can arise at the local, regional, national or global level. Learning networks create broader social relationships, not just focused on the learning processes.

In general, we can say that the learning worker is an expert in learning and his abilities lie in thinking, attitudes and values, which are manifested through:

- efforts to improve everything that is element of work,

- always thinking one step ahead to avoid time loss or work collisions,

- efforts to implement new things and assess and evaluate what could be done better,

- sharing information and knowledge with others (through articles, presentations, books, etc.).

In the pedagogical dictionary, this learning is characterized as "a lifelong process of acquiring knowledge, skills and attitudes from everyday experiences, from the environment and contacts with other people" [19]. It takes place in the family, among peers, at work, in leisure time, during traveling, reading books and magazines. Based on the above characteristics, as well as definition of the learning capital, is very problematic to operationalize and quantify this term. For this reason, we were forced to proceed with its reduction, which we describe in the methodological part of our paper.

Another key category is the economic growth, which is perceived by the authors in two ways: as a phenomenon in the narrower sense, or as a phenomenon in the broadest sense. In the narrower sense, they consider it to be a change in the standard of living of country (or defined territory), and in the broader sense, it represents any positive change - an increasing [20]. Economic growth is often seen as an increase in the level of production of goods and services per capita. J. Lisý perceives it as "the sum of the values of all final goods (consumer and investment) and services, produced and provided for a certain period of time (usually in one year) in territory of state" [21]. In order to fulfill the goal of our paper, we will perceive the economic growth in a similar way, but we will take into account the possibilities of its statistical processing.

\section{Methodological Framework of the Solved Problem}

In quantification based on the theoretical framework we identified the essence of three phenomena: globalization, the learning capital as one dimension of the human capital and economic growth and we also take into account the results of efforts of methodologists in this field.

\subsection{Quantification of Globalization}

In examining of globalization, we will came out from quantifier the KOF index, which is written by A. Dreher [22]. The index was first published in 2002, later edited in 2007 and 
most recently in 2017. From the point of extension of the whole issue, we draw attention to the synthetic index of globalization, which includes the values of economic, political and social globalization. We are using the second revision of the KOF Globalization Index. It is distinguishes between de facto and de jure globalization. While de facto globalization measures actual international flows and activities, de jure globalization measures policies and conditions that, in principle, enable, facilitate and foster flows and activities. The overall KOF Globalization Index combines de facto and de jure globalization. Therefore, in our measurement we take into account this type of index.

\subsection{Methodological Dilemmas of Learning Capital}

The methodological dilemmas lie in the quantification of the learning capital, as mentioned above. We can access it only through individual forms of the lifelong learning, which are formal and non-formal education [23, 11]. The informal education is still not included in statistical surveys. In both cases, in formal and non-formal education, it is an organized activity aimed at acquiring the knowledge, skills and abilities needed to perform specific activities, while these activities are performed institutionally. The formal education leads to obtaining a diploma or a certificate of education. Informal, it does not finish with an exam. It represents organized education outside from the formal system. It provides education for adults, young people with different content and learning needs. It is performed on a voluntary basis. Its implementers are civic associations, associations, foundations, professional associations, etc.

Efforts to quantify the learning capital through different forms of the lifelong learning lead us to the following conclusions:

1. At the organizational level, we can map all components of the learning capital, which means, that we can evaluate formal, non-formal and informal education, or learning, and compare its effects in relation to the strategic goals. However, organizations use the results of such research primarily for their own monitoring and do not provide information to an institution that would synthesize similar data from other companies. It is only a small and partial research, using a specific methodology, unique to the organization.

2. At the macro level, a wide range of indicators are monitored by the Ministry of Education, Science, Research and Sport of the Slovak Republic, they are applicable within the national statistics in the educational sector, concerning all subjects of the educational process, but only in the field of formal education.

Despite the important position of the learning capital, within the human capital, its monitoring at the macro and micro level is forgotten. There are no developed methodologies as well as quantification procedures for revealing relationships or dependencies of the learning capital, and no attempts to identify its determinative effects on the development and prosperity of society. We believe that our partial findings will support these efforts in the future.

\subsection{Quantification of Economic Growth}

The economic growth is most often measured by total state production such as gross domestic product (GDP) or gross national product (GNP or national income, etc.). It is also perceived as a change in the GDP of a particular state. Frequent modification of GDP in practice uses GDP per capita. If we divide GDP by the number of inhabitants, we get the average value of output of economy per capita, which is given in two world currencies: USD and EUR. The given indicator makes it possible to compare the performance of the national economies of different countries and to compile the rankings of success relatively 
accurately. Of course, like any indicator, it has its strengths and weaknesses. In our analysis, we will be based on the values of GDP per capita in purchasing power parity (Purchasing Power Standard - PPS).

\section{Empirical Findings and Discussion}

In our research, we will focus on finding the interconnectedness of all three phenomena, which are globalization, the economic growth and the learning capital. The reason is that we consider this form of relations to be one of priorities for shaping the economic policy in the future.

\subsection{Globalization, Learning Capital and Economic Growth}

In globalization we will use the KOF Globalization Index and its individual dimensions, as we mentioned in the methodological part of paper, in the economic growth GDP per capita in purchasing power parity (Purchasing Power Standard - PPS) and in the learning capital the Human Development Index database, which is currently being developed into several dimensions, concerning the level of literacy of the adult population, the combined rate of enrollment in primary, secondary and higher education, as well as the quality of education. We applied the relational analysis to the EU Member States (28) and examined the interconnectivity between them. In the case of globalization and the economic growth we used databases of 2015-2019 years and in relationship between globalization and the learning capital as well as the economic growth and the learning capital data of 2018 year. We used Pearson's correlation coefficient. We tested the following hypotheses:

1. The phenomenon of globalization and the economic growth are closely related, on the basis of which we can expect that the intensification of globalization will also support the results of the national economy.

2. There exists interconnection between the learning capital and globalization, as well as the learning capital and the economic growth. Therefore, it can be expected that by increasing the level of the learning capital, we will initiate positive changes in the field of the economic growth as well as globalization.

Our assumption that the phenomenon of globalization and the economic growth are closely related, was only partially confirmed. Based on the examination of the years 2015 2019, we can state, that in 2015 there was a moderately strong correlation (0.549328), which later in the years 2018 - 2019 reduced its intensity. In 2018 it showed a weaker intensity (0.399291) and in the following year the intensity of correlation further decreased (0.351922).

We made the interesting findings by examining the internal structure of the KOF Index and the economic growth. Although the more intense link between the two phenomena has not been globally confirmed, the interconnectedness of the partial components of the KOF Index - specifically in economic and social globalization - has been marked. The connection between the economic growth and the economic globalization achieved intensity of 0.559134 and the connection of the economic growth with the social globalization still higher, with value 0.758948 . 


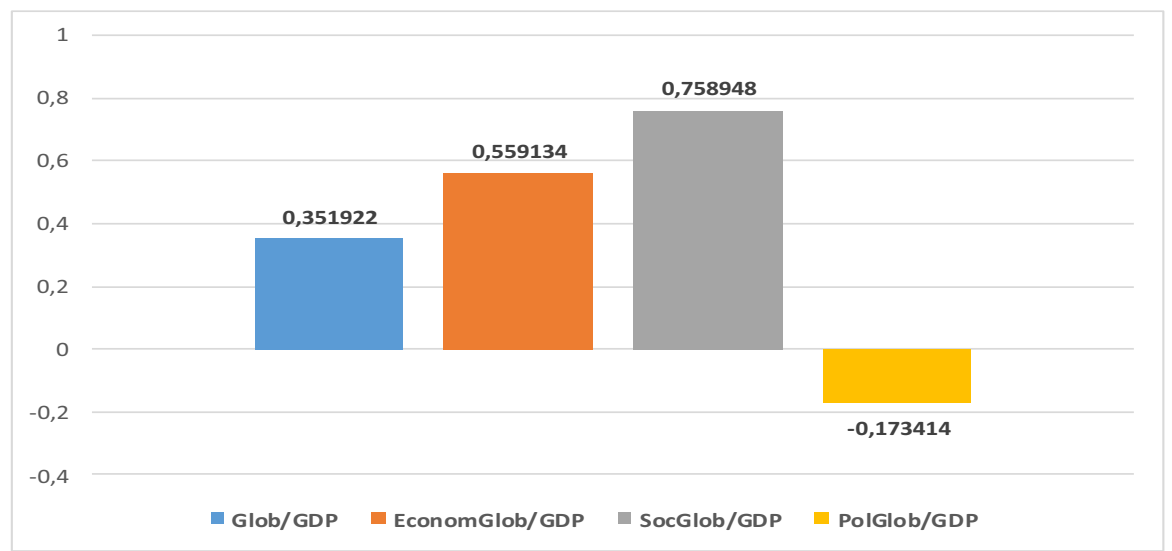

Fig. 1. Globalization and Economic Growth in 2019

Source: Own processing according to Eurostat Database and KOF Index Database

For verifying the second hypothesis about the link between the learning capital and globalization, as well as the learning capital and the economic growth, it was necessary to create a database for the learning capital. In the theoretical and methodological part of our paper, we stated the problem of operationalization of category and its necessary reduction due to the vacuum of statistical data. In our case, we will use database of the Human Development Index, specifically the following indicators:

1. Expected years of schooling: Number of years of schooling that a child of school entrance age can expect to receive if prevailing patterns of age-specific enrolment rates persist throughout the child's life.

2. Mean years of schooling: Average number of years of education received by people ages 25 and older, converted from education attainment levels using official durations of each level.

3. Pupil-teacher ratio, primary school: Average number of pupils per teacher in primary education.

4. Schools with access to the Internet: Percentage of schools at the indicated level with access to the Internet for educational purposes.

5. Programme for International Student Assessment (PISA) score: Score obtained in testing of skills and knowledge of 15 -year-old students in mathematics, reading and science.

6. Inequality in education: Inequality in distribution of years of schooling based on data from household surveys estimated using the Atkinson inequality index. [24, 25].

Table 1 shows the interconnectedness of three phenomena of the learning capital, globalization and the economic growth in 2015 and 2018. From the learning capital, we selected the indicators Expected years of schooling and Mean years of schooling. Their correlation analysis confirms the increasing trend of this interconnection from 2018 compared to 2015 , but the intensity of relations is weak. It represents interval $<0.228768-$ $-0.29942>$. If we compare the relationship between globalization and the economic growth, we can state that the learning capital in the indicator of Mean years of schooling shows the strongest connection with the economic growth, with almost the same intensity in both years examined. In 2015, the correlation achieved an intensity of -0.29942 and in 2018 year -0.2825 . 
Table 1. Correlation Analysis

\begin{tabular}{|l|r|r|}
\hline \multicolumn{1}{|c|}{ Relationship } & $\mathbf{2 0 1 5}$ & \multicolumn{1}{c|}{$\mathbf{2 0 1 8}$} \\
\hline Glob/Expec & 0,11901 & $-0,13947$ \\
\hline Glob/Mean & $-0,07477$ & 0,08959 \\
\hline GDP/Expec & 0,22877 & $-0,05985$ \\
\hline GDP/Mean & $-0,29942$ & $-0,28250$ \\
\hline
\end{tabular}

Source: Own processing according to HDI Database and KOF Index Database.

We reduced the examination of other components of the learning capital to 2018 year due to the scale of the issue. We analyzed the following indicators: Inequality of Education, Pupil Teacher Ratio, Access to the Internet, and PISA score.

Table 2. Correlation Analysis of Globalization and Learning Capital

\begin{tabular}{|l|r|}
\hline \multicolumn{1}{|c|}{ Relationship } & \multicolumn{1}{c|}{ Coefficient } \\
\hline Glob/Inequality in Education & 0,211704 \\
\hline Glob/Pupil Teacher Ratio, Primary School & $-0,102900$ \\
\hline Glob/ Primary Schools with Access to the Internet & 0,196430 \\
\hline Glob/ Secondary Schools with Access to the Internet & 0,193688 \\
\hline Glob/PISA1 (Mathematics) & 0,619959 \\
\hline Glob/PISA2 (Reading) & 0,553124 \\
\hline Glob/PISA3 (Science) & 0,571245 \\
\hline
\end{tabular}

Source: Own processing according to KOF Index Database and HDI Database.

Table 2 as well as Figure 2 shows the link between the learning capital and globalization. The interconnectedness of both phenomena is strongest in the Program for International Student Assessment (PISA) score.

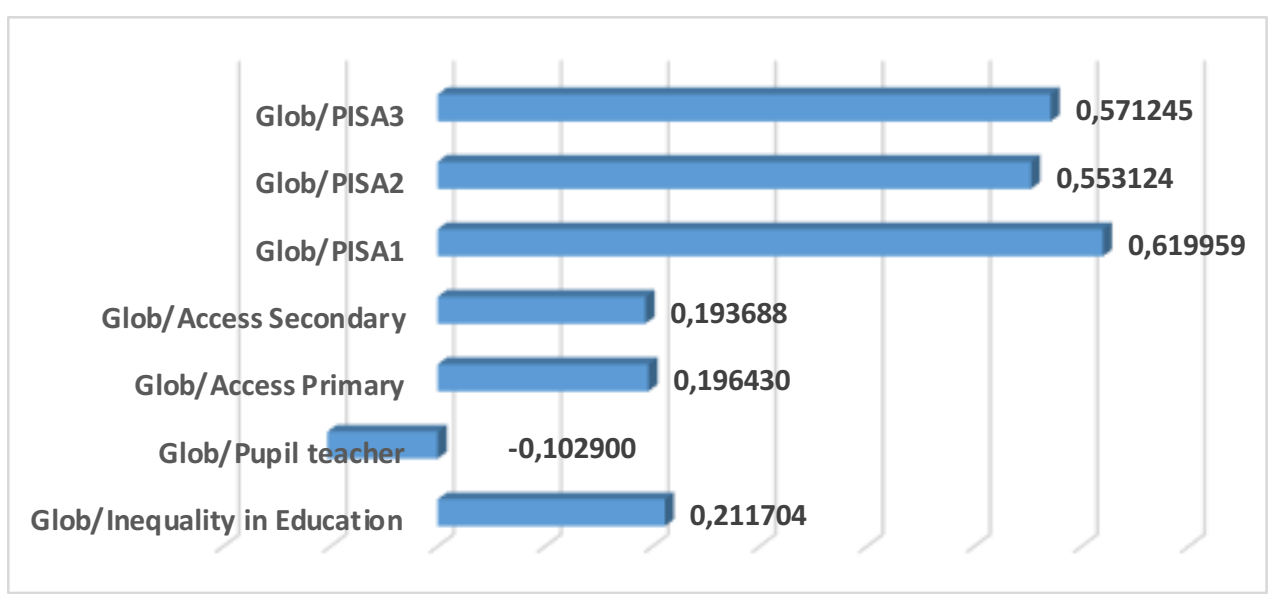

Fig. 2. Correlation Analysis of Globalization and Learning Capital

Source: Own processing according to KOF Index Database and HDI Database

This Score obtained in testing of skills and knowledge of 15-year-old students in mathematics, reading and science. PISA1 means skills and knowledge in mathematics, PISA2 - skills and knowledge in reading and PISA 3 - skills and knowledge in science. The 
strongest relationship was found between globalization and the PISA score from the field of mathematics (0.619959), slightly weaker in the field of science $(0.571245)$ and in the field of reading $(0.553124)$ it is the weakest. Although a weak link was confirmed between globalization and Inequality of Education with value of Pearson coefficient of 0.211704. Other indicators such as Internet access in primary and secondary schools, as well as the number of pupils per teacher, were insignificant.

Table 3. Correlation Analysis of Economic Growth and Learning Capital

\begin{tabular}{|l|r|}
\hline \multicolumn{1}{|c|}{ Relationship } & Coefficient \\
\hline GDP/Inequality in Education & 0,19848 \\
\hline GDP/Pupil Teacher Ratio, Primary School & $-0,56500$ \\
\hline GDP/Primary Schools with Access to the Internet & $-0,19669$ \\
\hline GDP/Secondary Schools with Access to the Internet & $-0,19646$ \\
\hline GDP/PISA1 (Mathematics) & 0,38182 \\
\hline GDP/PISA2 (Reading) & 0,34187 \\
\hline GDP/PISA3 (Science) & 0,30306 \\
\hline
\end{tabular}

Source: according to Eurostat Database and HDI Database.

Table 3 as well as Figure 3 present the link between the learning capital and the economic growth. In contrast to the previous link between globalization and PISA results, the correlation in the economic growth has been much more modest. There is also the strongest PISA score relationship in the field of mathematics $(0.38182)$, it was more pronounced in the field of reading (0.34187) and the slightest in the field of science (0.30306).

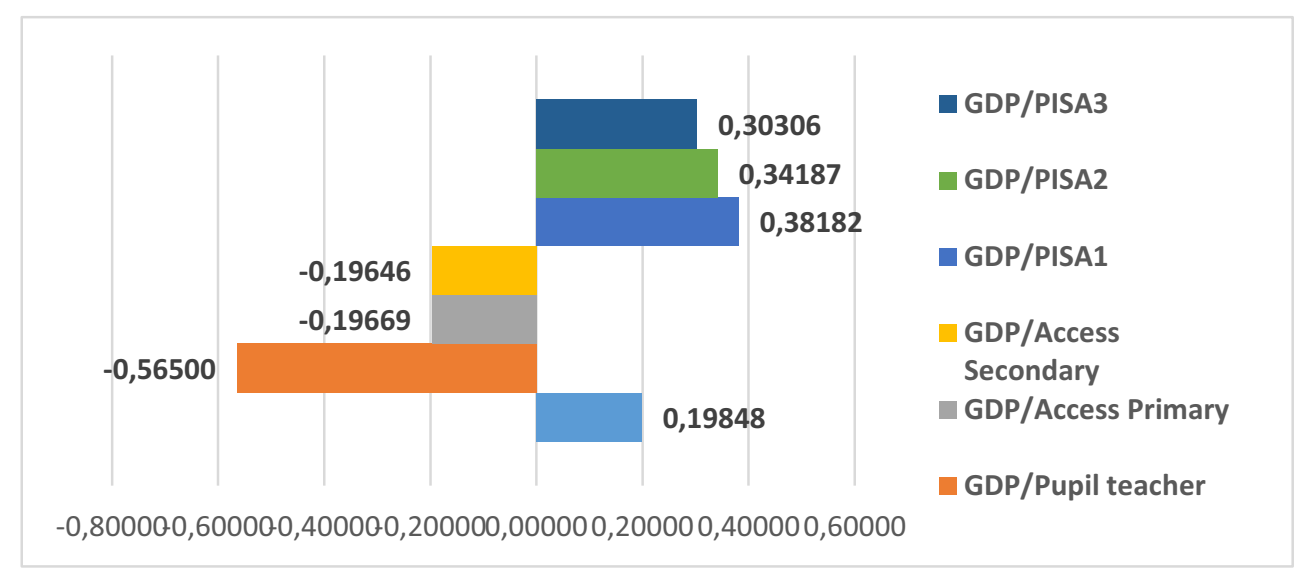

Fig. 3. Correlation Analysis of Economic Growth and Learning Capital

Source: Own processing according to Eurostat Database and HDI Database.

We recorded the most significant correlation in the Pupil Teacher Ratio indicator with a value of -0.56500 . In other indicators such as Inequality of Education, Primary and Secondary Schools with Access to the Internet, the Pearson correlation coefficient reached a very low value, only around 0.19 . 


\section{Conclusion}

In many economies of the European Union, the question remains of what causes the economic growth in country. Whether they are technological change, globalization influences or human capital. For this reason, in our analysis, we aim to examine the interconnectedness of globalization, the economic growth and the learning capital. We emphasize the learning capital, not human capital, which we perceive as a global phenomenon consisting of dimensions: the learning capital, the knowledge capital, the creative capital and the social capital. The learning capital is the most problematic of them, whether in theoretical, methodological or empirical level. Despite this fact, we verified the interconnectedness of all three mentioned phenomena, in which we a priori assumed that there exists a strong connection between them. Our assumption, that the phenomenon of globalization and the economic growth are closely related was only partially confirmed, because the correlation between them in 2015-2019 had a declining trend. Regarding to the strong connection between the learning capital and the economic growth, as well as the learning capital and globalization, we can state only partial interrelationships.

In conclusion, we want to notice the existing vacuum of information in the dimension of the learning capital, especially in the area of its operationalization and quantification. This fact creates barriers in the deeper analysis of the human capital, as the basis for the economy itself. Its examination in the mentioned dimensions brings more specific and deeper knowledge about the current and future needs of the human development as well as the labor market itself, without which it is not possible to form the economic policy.

Writing this paper was supported by the project VEGA no. 1/0251/19 "Housing Investment in Households and the Possibility of Their Alternative Using as an Additional Income at the Time of Receiving the Pension Benefit".

\section{References}

1. European Commission (2020). European semester. Retrieved from : http://ec.europa.eu/europe2020/europe-2020-in-a-nutshell/index_sk.htm

2. Šikula, M. (2005). K metodologickým východiskám ponímania fenoménu globalizácie. Ekonomický časopis, 53(7), 663-679.

3. Krugman, P., Venables, A., J. (1995). Globalization and the inequality of nations. The Quarterly Journal of Economics, 110(4), 587-880.

4. Broner, F., Ventura, J. (2016). Rethinking the effects of financial globalization. The Quarterly Journal of Economics, 131(3), 1497-1542.

5. Schularick, M., Solomou, S. (2011). Tariffs and economic growth in the first era of globalization. Journal of Economic Growth, 16, 33-70.

6. Witt, M. A. (2019). De-globalization: Theories, predictions, and opportunities for international business research. Journal of International Business Studies, 50(4), 10531077.

7. Jeníček, V. (2002). Globalizace světového hospodárství. Praha: C. H. Beck.

8. OECD (2005). OECD Handbook on economic globalization indicators. OECD.

9. Clark, W. C. (2000). Governance in a globalizing world, environmental globalization. Brooking Institution Press.

10. Križan, F., Bilková, K., Kita, P., Siviček, T. (2016). Transformation of retailing in post-communist Slovakia in the context of globalization. Economics and Management, 19(1), 148-163. 
11. Becker, G. S. (1994). Human capital: a theoretical and empirical analysis, with special reference to education. Chicago: University of Chicago Press.

12. Crawford, R. (1991). In the era of human capital. New York: Harpercollins.

13. Stokey, N. L. (1991). Human capital, product quality and growth. The Quarterly Journal of Economics, 106(2), 587-616.

14. Acemoglu, D. (1996). A microfoundation for social increasing returns in human capital accumulation. The Quarterly Journal of Economics, 111(3), 779-804.

15. Coleman, J. S. (1988). Social capital in the creation of human capital". American Journal of Sociology, 94, 95-120.

16. Elshafie, E. M. (2018). Toward a knowledge-based economy. Learning university is a key prerequisite. Journal of International Business Research, 17(1), 1-20.

17. Vialle, W., Stoeger, H. (2018). Educational and learning capital: implications for gifted education. Journal for the Educatin of the Cifted, 41(4), 295-297.

18. Edwards, R. (1997). Changing places? Flexibility, lifelong learning and a learning society. London: Routeldge.

19. Průcha, J., Walterová, E., Mareš, J. (2008). Pedagogický slovník. Praha: Portál.

20. Lisardo, E., Marcel te Kaat, D. (2019). Inequality and growth: industry-level evidence. Journal of Economic Growth, 24(2), 283-308.

21. Lisý, J. (2005). Makroekonómia 1. Výkonnost' ekonomicky a ekonomický rast. Bratislava: Iura Edition.

22. Dreher, A. (2006). Does globalization affect growth? Evidence from a new index of globalization. Applied Economics, 38(10), 1091-1110.

23. European Commission (2000). Memorandum o celoživotnom vzdelávaní sa. Brussels.

24. United Nations Development Programme (2019). Human development report 2019. The united nations development programme. New York: UNDP.

25. United Nations Development Programme (2018). Human development indices and indicators. The united nations development programme. New York: UNDP. 